\title{
THE PHENOMENON OF CYBERSUICIDE: AN EXAMINATION OF AUSTRALIA'S SOLUTION, THE CRIMINAL CODE AMENDMENT (SUICIDE RELATED MATERIAL OFFENSES) ACT 2005 AND THE DIFFICULTY OF INTERNATIONAL IMPLEMENTATION
}

\author{
Jennifer L. Prinz*
}

\section{INTRODUCTION}

The debate over the legalization of assisted suicide occurs in nearly every nation. ${ }^{1}$ This debate increased in complexity and intensity with the development of internet websites promoting different methods of suicide and counseling internet users to commit suicide. ${ }^{2}$ Now, legislators around the world and the public alike deliberate on whether to regulate these websites under

* J.D., Indiana University School of Law - Indianapolis, May 2008. B.A. Indiana University 2005.

1. Penney Lewis, Article, Rights Discourse and Assisted Suicide, 27 AM. J.L. AND MED. 45, 45. (2001). The American Medical Association has ethical concerns with assisted-suicide because it is "contrary to the traditional prohibition [of the medical community] against using the tools of medicine to cause a patient's death." American Medical Association, Decisions Near the End of Life, CEJA REPORTS, A-91 (1991), available at www.amaassn.org/ama1/pub/upload/mm/369/ceja_ba91.pdf. A majority of states have laws criminalizing assisted suicide. See Cruzan v. Director, Mo. Dep't of Health, 497 U.S. 261, 280 (1990). In 1994, the State of Oregon enacted legislation legalizing physician-assisted suicide. See OR. REV. STAT. \$\$127.800-127.897 (1994). In January 2006, the United States Supreme Court upheld the statute. Gonzales v. Oregon, 546 U.S. 243, 274-75 (2006). Internationally, many have made assisted suicide illegal. See Suicide Act, 1961, c. 60, § 2 (Eng.); Crimes Act, 1900, § $31 \mathrm{C}$ (NSW); Criminal Code, R.S.C. ch. C-46, § 241 (1985); Gonzalo Casino, Film Reopens Euthanasia Debate in Spain, BRIT. MED. J., Oct. 9, 2004 (stating Spain deems assisted suicide and euthanasia as crimes); B.C. Civil Liberties Association, Assisted Suicide and Active Voluntary Euthanasia, BCCLA, (1988), available at http://www.bccla.org/positions/privateoff/88euthanasia.html (discussing the Italian Penal Code criminalizing assisted suicide, but indicating the action is more punishable if the suicide is successful). Assisted suicide is legal in the Netherlands, Belgium, and Switzerland. Assisted Suicide: The Fight for the Right to Die, CBC NEWs, June 11, 2007, available at http://www.cbc.ca/news/background/assistedsuicide/.

2. See Patrick Goodenough, Websites Promoting Suicide Should be Outlawed, Some Say, CNSNEWS.COM INT'L EDrroR, Sept. 12, 2006, available at http://www.cnsnews.com/news/viewstory.asp?Page=/ForeignBureaus/archive/200609/INT2006 0912a.html (stating a charity in Britain is pushing for the government to act against Internet websites promoting suicide); Greg Barnes, New Law on Suicide Attacks Freedom, THE CANBERRA TIMES, Jan. 6, 2006, available at http://www.onlineopinion.com.au/view.asp?article $=4022$ (attacking the Criminal Code Amendment (Suicide Related Material Offences) Act 2005 because it is "an attack on freedom of communication" and a "fundamental human right"). 
current assisted-suicide legislation or whether new regulation addressing the legality of these sites is required. ${ }^{3}$

Commentators refer to the relatively new phenomenon of pro-suicide websites as cybersuicide. ${ }^{4}$ Cybersuicide websites include sites detailing specific ways of how to commit suicide, ${ }^{5}$ which methods are most painless, ${ }^{6}$ online content offering psychological guidance promoting suicide, ${ }^{7}$ chat rooms and bulletin boards with messages of death wishes, suicide pacts, or advertisements looking for others with whom one can commit suicide. ${ }^{8}$ Some websites even sell kits containing the necessities to commit suicide. ${ }^{9}$

Since the late $1990 \mathrm{~s}$, internet users around the world have used the internet to create suicide pacts. ${ }^{10}$ This is a quickly expanding fad as evidenced by the plethora of websites found online. ${ }^{11}$ There are tens of millions of websites available over the internet discussing suicide. ${ }^{12}$ Various locations such as Holland, the United States and Japan host these websites. ${ }^{13}$ Internet users can easily utilize popular internet search engines to find cybersuicide websites. ${ }^{14}$ In a study published in the Eubios Joumal of Asian and International Bioethics, a group conducted an internet search utilizing the search engine Google with the query "how to suicide" and received 179 sites, a number of which featured different ways to commit suicide. ${ }^{15}$ In researching

3. See generally Peter Dutton, Criminal Code Amendment (Suicide Related Material Offences) Bill 2004: Second Reading, Aug. 11, 2004, available at http://www.peterdutton.com.au/news/default.asp?action=article\&ID=468; Letter from Jocelyn Head, President, Voluntary Euthanasia Society of Tasmania, to The Senate Legal and Constitutional Committee (Mar. 27, 2005) available at http://www.aph.gov.au/senate/committee/legcon_ctte/suicide/submissions/sub06.pdf.

4. Calson Analytics, Calson Analytics Note Cybersuicide,

(2005) http://www.caslon.com.au/cybersuicidenote.htm.

5. Id. An example includes an academic paper entitled, "Want to know how to behead yourself? Just go online." Id.

6. J. Sean Curtin, Suicide in Japan: Part Sixteen-Suicide Websites, JAPANESE INST. OF Global CoMm., Oct. $\quad$ Oc, 2004, http://www.glocom.org/special_topics/social_trends/20041020_trends_s89/index.html.

7. Calson Analytics, supra note 4.

8. Curtin, supra note 6.

9. Id. In 1998, authorities discovered a science teacher was dispensing cyanide pills to suicidal people who contacted him over the internet. Id. After authorities attributed several cyanide-related suicides to the website, authorities shut down the website. Id.

10. 430 PARL. DEB., H.C. $\left(6^{\text {th }}\right.$ ser.)(2005) 278 (noting that known cases of suicide pacts have occurred internationally from Guam to the Netherlands).

11. See, e.g. A Practical Guide to Suicide, http:/www.satanservice.org/coe/suicide/guide/ (last visited May 22, 2008); see also Michael Marsden, Methods File, http://www.ctrlc.liu.se/ ingvar/methods/ (last visited May 22, 2008).

12. Press Association, Charity in Suicide Websites Call, Sept. 9, 2006, http://news.bbc.co.uk/2/hi/health/5327354.stm [hereinafter Charity in Suicide Websites].

13. Id.

14. Goodenough, supra note 2.

15. Vinod Scaria, Ph.D., A Discussion on the Perspectives of Suicide Related Information on the Internet, 13 EUBIOS J. OF ASIAN AND INT'L BIOETHICS 175 (2003), available at http://drvinod.netfirms.com/preprintejaib2.htm. 
the Australian Criminal Code Amendment (Suicide Related Material Offenses) Act 2005, one Member of Parliament was able to access more than 7,230,000 hits in a tenth of a second after typing the query "how to kill yourself" into Google. ${ }^{16}$ Many of these sites, however, have a disclaimer warning users of their dangerous content. ${ }^{17}$

Though research pertaining to the users of these sites is minimal, early findings indicate young people are frequent visitors. ${ }^{18}$ Often, teenagers access the websites after suffering from bullying, emotional problems, or merely morbid curiosity. ${ }^{19}$ Most of the call to action initiated in this field cites the protection of the young and vulnerable as its main aim, because these sites are "too easily accessible for these often unsupervised age groups." ${ }^{\text {, }}$ The easy accessibility of these sites becomes even more dangerous when one considers teenagers in the age bracket of fifteen to nineteen have the highest internet usage of any age demographic. ${ }^{21}$ When suffering from depression or other adolescent angst issues, vulnerable teenagers could be put in danger by viewing websites encouraging suicide ${ }^{22}$ because teenagers in such susceptible situations are not "mentally mature and their judgments are easily affected by other things." ${ }^{23}$ In fact, the only legislation regulating cybersuicide websites passed thus far, Australia's Criminal Code Amendment (Suicide Related Material Offenses) Act 2005, was created with the goal of protecting young and innocent

16. Legal and Constitutional Legislation Committee, Parliament, Provisions of the Criminal Code Amendment (Suicide Related Material Offenses) Bill 2005, (2005) 29, available at http://www.aph.gov.au/senate/committee/legcon_ctte/suicide/report/report.pdf [hereinafter Provisions of the Criminal Code Amendment]. But see Letter from Electronic Frontiers Australia, Inc. to the Senate Legal and Constitutional Committee (Apr. 3, 2005), available at http://www.efa.org.au/Publish/efasubm-slclc-suic2005.html (noting that "while a search using terms such as 'suicide how to' returns millions of results, this provides no indication" of the number of sites actually providing methods of committing suicide). "Web site providers intending to discourage people from committing suicide often use terms such as 'how to' in meta tags to attract at-risk people to their sites." Id.

17. Curtin, supra note 6. For example, one website listing several methods of suicide had a disclaimer indicating the website provided the file for "amusement" and the use of any of the methods was "not recommended without first considering other possibilities." Marsden, supra note 11. The site also warns its viewers to not pass the site on to those known to be "actively suicidal," because it could constitute assisted suicide. Id.

18. Curtin, supra note 6.

19. Id.

20. Dutton, supra note 3.

21. Id. Because of statistics demonstrating teenagers have the highest internet usage of any age group, Papyrus, a charity in Britain, is requesting the government to initiate legislation against cybersuicide sites to protect vulnerable teenagers. Goodenough, supra note 2. But see Letter from Jocelyn Head to the Senate Legal and Constitutional Committee, supra note 3 (noting that while young people do access the internet more frequently than those in the older demographics, adolescents use the internet for leisure pursuits. Older people use the internet to "search for usable information or to contact friends and family").

22. Dutton, supra note 3.

23. Alice Yan, CHINA: Crackdown on internet 'suicide manuals,' SOUTH CHINA MORNING POST, Apr. 1, 2005, available at 2005 WLNR 5051399. 
individuals. ${ }^{24}$ Those opposing who oppose the legislation in Australia find the goal of protecting the young and vulnerable discounts the elderly and terminally ill population who may benefit from the existence of cybersuicide websites. ${ }^{25}$

Specific cybersuicide websites are linked to suicides in several countries, including Britain, the United States, Japan, and South Korea. ${ }^{26}$ In the United Kingdom, at least sixteen adolescent suicides since 2001 have been deemed internet-related suicides. $^{27}$ Japan reported at least fifty-four people killed themselves in 2004 through internet-linked group suicide pacts, even though police recognize the number is probably higher. ${ }^{28}$ In 2006 , Japanese police stated the number of people who committed suicide after creating suicide pacts over the internet had risen to ninety one in $2005 .^{29}$

While these statistics demonstrate that cybersuicide websites have been the direct cause of several suicides, cybersuicide websites are difficult to shutdown. ${ }^{30}$ First, the character of the internet allows information to pass freely from one segment of the world to another. ${ }^{31}$ This gives legislatures and courts alike the challenge of determining who exactly has jurisdiction over the issue. ${ }^{32}$ It is also questionable whether the law of one country will pertain to websites hosted in another country; this is evidenced by a United Kingdom Parliament spokesman who considered whether the current United Kingdom law on assisted-suicide, the 1961 Suicide Act, is applicable to cybersuicide websites hosted in other countries. ${ }^{33}$

Secondly, many national laws on assisted-suicide, such as the 1961

24. Dutton, supra note 3. In creating this legislation for the protection of adolescents, the Australian government noted fifty-five percent of children between the ages of ten and fourteen use the internet. Id.

25. Goodenough, supra note 2. In response to an inquiry over Australia's Suicide Related Material Offenses Bill, Sandra Milne, of Voluntary Euthanasia Society of Queensland, responded in opposition to the Bill based on how it would affect the elderly population of Australia. Letter from Sandra Milne, for Voluntary Euthanasia Society of Queensland, to the Senate Legal and Constitutional Committee (Aug. 20, 2004), available at http://www.aph.gov.au/senate/committee/legcon_ctte/suicide/submissions/sub15.pdf. In her letter, Milne referred to statistics from the Australian Bureau of Statistics, stating each week three persons over the age of seventy-three commit suicide in the most horrendous ways possible. Id. It was her belief these people may have lived if they had discussed their intention through cybersuicide websites or other pro-euthanasia websites. Id. With Australia's new law, Milne feared more suicides from the elderly would occur. $I d$.

26. Goodenough, supra note 2.

27. Charity in Suicide Websites, supra note 12.

28. Australian Government to Outlaw Suicide Websites, New Zealand Herald, Mar. 9, 2005, available at http://www.nzherald.co.nz/section/story.cfm?c_id=5\&objectid=10114232.

29. Calson Analytics, supra note 4.

30. Curtin, supra note 6.

31. Steven M. Hanley, International Internet Regulation: A Multinational Approach, 16 J. MARSHALL J. COMPUTER \& INFO. L. 997, 999-1000 (1998).

32. Ray August, International Cyber-Jurisdiction: A Comparative Analysis, 39 AM. Bus. L.J. 531, 532 (2002).

33. Call to Ban Pro-suicide Websites, BBC News, Sept. 9, 2006, available at http://news.bbc.co.uk/2/hi/health/5327354.stm [hereinafter Call to Ban Pro-suicide Websites]. 
Suicide Act, require a direct causal link between the information provided by the accused and the act of suicide. ${ }^{34}$ In countries with laws requiring a causal link, it is not enough to show the victim received advice and encouragement to commit suicide. ${ }^{35}$ Rather, the prosecution must be able to show a direct link between the encouragement given and the suicide. ${ }^{36}$

Third, regulation of the websites could also impinge on the rights of freedom of expression ${ }^{37}$ and freedom of communication. ${ }^{38}$ Fourth, when a website is shut down, the nature of the internet allows the site to simply move to another internet address until it is discovered again. ${ }^{39}$ Lastly, neither discussing suicide nor discussing a desire to commit suicide is illegal. ${ }^{40}$ In response to an inquiry on the Suicide Related Material Offenses Act, Jocelyn Head, of the Voluntary Euthanasia Society of Tasmania, Inc., stated such regulation makes illegal a formerly legal act. ${ }^{41}$ Head stated, "suicide is not a crime and it is reasonable for any adult to seek information regarding any legal act. ${ }^{, 2}$ She further expressed distaste for the illegality of providing information to a rational adult about a legal act, regardless of how the information is used. ${ }^{43}$ These reasons place limits on the ability of governments to regulate such sites. $^{44}$

This Note will examine constitutional difficulties and other legal battles standing in the way of an international solution to the phenomenon of cybersuicide. Part II of this Note will examine the Criminal Code Amendment (Suicide Related Material Offenses) Act 2005, the only current legislation that addresses cybersuicide websites and online counseling encouraging others to commit suicide. ${ }^{45}$ This section will discuss how the Australian Parliament overcame many legal roadblocks in order to pass the legislation and the problems that still exist with the current version of the law.

Part III of this Note will detail the extreme problem of cybersuicide in the United Kingdom and the call for regulation on these websites by Papyrus, a suicide prevention group ${ }^{46}$ and the Members of Parliament. ${ }^{47}$ This Note will also explore various options the government has considered in regulating this activity, such as following the Australian Suicide Related Material Offenses

34. Goodenough, supra note 2. See also Suicide Act, 1961, c. 60, § 2 (Eng.).

35. Charity in Suicide Websites, supra note 12.

36. Id.

37. Curtin, supra note 6.

38. See generally Barnes, supra note 2 .

39. Curtin, supra note 6.

40. Id.

41. Letter from Jocelyn Head to the Senate Legal and Constitutional Committee, supra note 3 .

42. Id.

43. Id.

44. Curtin, supra note 6.

45. Criminal Code Amendment (Suicide Related Material Offenses) Act, 2005 (Austl.).

46. See Goodenough, supra note 2; Charity in Suicide Websites, supra note 12.

47. 430 PARL. DEB., H.C. $\left(6^{\text {th }}\right.$ ser.)(2005) 276. 
Bill $^{48}$ or amending the 1961 Suicide Act. $^{49}$

In providing a brief conclusion, Part $\mathrm{V}$ of the Note will discuss the need for international attention to the problem of internet suicide; however, this Note will also recognize an international solution may not exist because of the difficulty in regulating the internet internationally.

\section{THE Australian Solution to CyBERsuicide: THE SUICIDE RELATED MATERIAL OFFENSES BILL}

The Suicide Related Material Offenses Act is a controversial regulation introduced in Australia in January $2006 .^{50}$ Section A will discuss a brief history of assisted-suicide laws in Australia that form the basis of this regulation of assisted-suicide over the internet and other telecommunication devices. Section B will provide statistics of the suicide rates in Australia and the country's new problem with the phenomenon of cybersuicide. Section $\mathrm{C}$ will briefly describe the history of the Act from its birth to its enactment. Section D will provide an analysis of the Act, including statutory interpretation and the legal ramifications the Act has faced and will face.

\section{A. A Brief History of Assisted-Suicide Laws in Australia}

As the separate statutes of the Australian territories show, assisted suicide has historically been illegal in Australia for the past century. ${ }^{51}$ An example of an Australian territory's law on assisted-suicide, New South Wales' Crimes Act $190031 \mathrm{C}$, states a person who "aids or abets the suicide or attempted suicide of another person shall be liable to imprisonment for [ten] years." ${ }^{\text {, Under this }}$ statute, when a person incites or counsels another person to commit suicide and the said person commits or attempts to commit suicide because of such counseling and incitement, the assisting individual faces up to ten years of imprisonment. $^{53}$

48. Id. at col. 281.

49. Id. at col. 282; see also Charity in Suicide Websites, supra note 12; see generally Calson Analytics, supra note 4 (noting one United Kingdom official's idea to lead internet users searching for cybersuicide websites to websites counseling him or her against committing suicide).

50. Criminal Code Amendment (Suicide Related Material Offenses) Act, 2005 (Austl.).

51. Crimes Act, 1900, \&31C (NSW); Crimes Act, 1900, \&17 (Austl. Cap. Terr.) available at http://www.austlii.edu.au//cgibin/disp.pl/au/legis/act/consol_act/ca190082/s17.html?query=suicide, (last visited May 22, 2008); Criminal Code, 1899, \& 311 (Queensl.) available at http://www.austlii.edu.au//cgibin/disp.pl/au/legis/qld/consol_act/cc189994/s311.html?query=suicide, (last visited May 22, 2008); Criminal Law Consolidation Act, 1935, \& 13A (S.A.) available at http://www.austlii.edu.au//cgi-

bin/disp.pl/au/legis/sa/consol_act/clca1935262/s13a.html?query=suicide, (last visited May 22, 2008).

52. Crimes Act, 1900, \& 31C (NSW).

53. Crimes Act s. 31C. 
In 1995, the Northern Territory Parliament in Australia passed the Rights of the Terminally Ill Act 1995 . $^{54}$ This law allowed terminally ill patients to end their lives with physician assistance as long as the parties followed strict guidelines. ${ }^{55}$ These guidelines included examinations by two doctors, one who specialized in terminal illness to determine the patient was terminally ill and another doctor who specialized in mental illness to confirm the patient was not clinically depressed. ${ }^{56}$ While the Rights of the Terminally Ill Act 1995 was in effect, four patients received assistance in dying legally. ${ }^{57}$

In response to concerns over the Rights of the Terminally Ill Act 1995, the Australian Parliament exercised its plenary power under Section 122 of the Australian Constitution and repealed the Act. ${ }^{58}$ The Euthanasia Laws Bill 1997 passed with the purpose and effect of preventing the Northern Territory, the Australian Capital Territory, and Norfolk Island from passing legislation permitting euthanasia. 59 As a result, a physician who "prescribes medical treatment with the intention of aiding the patient's death may be subject to life imprisonment." 60 Today, assisting or attempting to assist another to commit suicide is an offense in all Australian States and Territories ${ }^{61}$ with offenses including imprisonment from five years ${ }^{62}$ to life. ${ }^{63}$

With the passage of the Criminal Code Amendment (Suicide Related Material Offenses) Act 2005, the Australian Parliament has made it illegal for anyone in any territory of Australia to incite, promote, or teach people how to commit suicide over a carriage service. $^{64}$

54. Christopher Zinn, Australia Passes First Euthanasia Law, The Guardian, June 3, 1995, available at http://www.bmj.com/cgi/content/full/310/6992/1427/a.

55. Id.

56. Andrew L. Plattner, Article, Australia's Northern Territory: The First Jurisdiction to Legislate Voluntary Euthanasia, and the First to Repeal It, 1 DEPAUL J. HEALTH CARE L. 645, $647-48$ (1997).

57. Id.

58. Euthanasia Laws Bill, 1996 (Austl.). Section 122 of the Australian Constitution permits the Commonwealth to enact laws for the government of any territory. Id. "It may do so by means of paramount legislation passed by the Commonwealth Parliament, or by setting up a Territorial legislature with its own legislative power." Id. (quoting RD LUMB \& GA MOENS, THE CONSTITUTION OF THE COMMONWEALTH OF AUSTRALIA (5th ed., Butterworths 1995) (1867).

59. Euthanasia Laws Act, 1997 (Austl.). For example, Schedule 2 of this Act amending the Australian Capital Territory Act 1988, states Section 23(1A) shall read, "[t]he Assembly has no power to make laws permitting or having the effect of permitting ... the form of intentional killing of another called euthanasia or the assisting of another person to terminate his or her life." Euthanasia Laws Act, Schedule 2.

60. Plattner, supra note 56 , at 651 .

61. Criminal Code Amendment (Suicide Related Material Offenses) Act, 2005 (Austl.).

62. Crimes Act, $1900, \S 31 \mathrm{C}$ (NSW).

63. Criminal Code, 1899, § 311 (Queensl.) available at http://www.austlii.edu.au//cgibin/disp.pl/au/legis/qld/consol_act/cc189994/s311.html?query=suicide, (last visited May 17, 2008).

64. Criminal Code Amendment (Suicide Related Material Offenses) Act, 2005 (Austl.). 
B. High Suicide Rates in Australia, Mixed with Cybersuicide, is a Deadly Combination.

The suicide rate in adolescents between the ages fifteen to twenty-four years of age is alarming, as demonstrated by an Australia Bureau of Statistics survey indicating approximately seventeen per one-hundred thousand people in this age demographic committing suicide between the years $1996-1998 .^{65}$ This rate for the adolescent demographic was significantly higher than the rate in England, Wales, and the Netherlands. ${ }^{66}$ In 2002, Griffith University's Australian Institute for Suicide Research and Prevention found that at least $20 \%$ of Australians have considered life is not worth living, $10 \%$ have seriously considered committing suicide, and $3.1 \%$ have actually attempted suicide. ${ }^{67}$ Further, suicide is the number one cause of death for males aged twenty-five to forty-four in Australia. ${ }^{68}$ A 1999 suicide attempt study produced by the American Journal of Psychiatry and used by the Australian government in support of the Suicide Related Material Offenses Act showed access to online suicide methods increases the risk that those who contemplate suicide will commit suicide. $^{69}$

Mr. John Graham Preston, Queensland coordinator of Right to Life Australia, presented the government's case in support of the bill and cited a specific Australian suicide directly tied to the use of cybersuicide websites. ${ }^{70}$ In 2003 , a seventeen-year-old hung himself. ${ }^{71}$ Upon researching his death, police found graphic information from websites detailing suicide methods on his computer. ${ }^{72}$ In further support, the government referred to an article by Baume, Cantor, and Rolfe on Internet chat rooms and the story of Nick W., who stated, "I'm going to do it any day now, really, I promise."73 The trio found this

65. Australian Bureau of Statistics, Australian Social Trends, 2000: Mortality and Morbidity: Suicide, Apr.

7, 2000 , http://www.abs.gov.au/ausstats/abs@.nsf/2f762f95845417aeca25706c00834efa/d2c9296f8d9c0 $1 \mathrm{~b} 1 \mathrm{ca} 2570 \mathrm{ec000e2f5f!OpenDocument.}$

66. Letter from Festival of Light Australia to the Senate Legal and Constitutional Committee (Apr. 6, 2005), available at http://www.aph.gov.au/senate/committee/legcon_ctte/suicide/submissions/sub29.pdf (citing Dr. David Phillips, Youth suicide-why the epidemic, LiGHT, May 2002, at 9).

67. Legal and Constitutional Legislation Committee, Canberra, Reference: Criminal Code Amendment (Suicide Related Material Offenses) Bill 2005, (2005) L\&C 9 [hereinafter Reference: Criminal Code Amendment].

68. $1 d$.

69. Goodenough, supra note 2. It is important to note, in the time period starting with the availability of the internet in Australia and the date the Suicide Related material Offenses Bill was passed, the suicide rate actually decreased in Australia. Reference: Criminal Code Amendment, supra note 67, at L\&C 6.

70. Reference: Criminal Code Amendment, supra note 67, at L\&C 9.

71. Id.

72. Id.

73. Provisions of the Criminal Code Amendment, supra note 16, at 36 (quoting Baume et al., Cybersuicide: the Role of Interactive Suicide Notes on the Internet, 18(2) CRISIS: THE 
statement suggested the exposure to internet participation and encouragement from cybersuicide websites may have caused Nick to follow through on his suicide, rather than finding a healthy way to handle his feelings. ${ }^{74}$

The advent of the internet as a worldwide forum made it possible for " "widely scattered suicidal youngsters to rapidly and directly interact.", In addition, the teenage demographic is more susceptible to the cybersuicide websites and chat rooms based on their prevalent use of the internet. ${ }^{76}$ While Parliament conceded that no "detailed scientific study" or "extensive research project" prompted the creation of the Suicide Related Material Offenses Act, ${ }^{77}$ it is apparent the Act was a response to community concern over the risks of the internet ${ }^{78}$ coupled with public policy in protecting the vulnerable-mainly atrisk teenagers. ${ }^{79}$

In expressing his support for the Act, Dr. David M. Grawler noted that youth suicide rates are extremely high and he worried about the danger suicidal websites would have on "vulnerable, troubled youth and depressed people" in Australian society. ${ }^{80}$ Research used in support of the Bill shows that $7 \%$ to $14 \%$ of worldwide adolescents will inflict self-harm at some point in their life, and $20 \%$ to $45 \%$ of older adolescents reported having suicidal thoughts. ${ }^{81}$ The Australian Parliament fears vulnerable, young people "could be pushed over the edge to their deaths by individuals or groups promoting suicide." ${ }^{\text {. }}$ Research has shown that cybersuicide websites containing encouraging comments from other users can have the effect of strengthening the resolve of those contemplating suicide and result in their deaths. ${ }^{83}$ These readily accessible websites also have the potential to discourage others from seeking help. ${ }^{84}$ As a result of the comments which encourage suicide and discourage seeking help, vulnerable people feel so strongly compelled to commit suicide that they feel

Journal OF CRISIS INTERvention AND SuICIDE PREVENTION 73 (1997)).

74. Provisions of the Criminal Code Amendment, supra note 16, at 36.

75. Id. at 35 (citing L. Mehlum, The Intermet, Suicide, and Suicide Prevention, 21(4) CRISIS: The Journal of CRISIS INTER Vention AND SuiCide PRevention 186, 186-88 (2000)).

76. Reference: Criminal Code Amendment, supra note 67, at L\&C 4-5.

77. Provisions of the Criminal Code Amendment, supra note 16, at $\S 3.4$

78. Id.

79. Id. at 3.12 (citing Reference: Criminal Code Amendment, supra note 67, at L\&C 2).

80. Letter from Dr. David M. Gawler, of Royal Darwin Hospital, to the Senate Legal and Constitutional Committee (Aug. 20, 2004), available at http://www.aph.gov.au/senate/committee/legcon_ctte/suicide/submissions/sub12.pdf.

81. Provisions of the Criminal Code Amendment, supra note 16, at 39 (citing K. Hawton and A. James, Suicide and Deliberate Self Harm in Young People, 330 BRIT. MED. J. 891 (2005)).

82. Provisions of the Criminal Code Amendment, supra note 16, at 39.

83. Id. (citing S. Thompson, The Internet and its Potential Influence on Suicide, 23 PSYCHIATRIC BULLETIN 449-451 (1999)).

84. Provisions of the Criminal Code Amendment, supra note 16, at 7 (citing Philip Ruddock, Criminal Code Amendment (Suicide Related Material Offenses) Bill 2005: Second Reading, 4-5 (2005), available at http://parlinfoweb.aph.gov.au/piweb/view_document.aspx?ID=2413765\&TABLE=HANSARD R). 
backing out or seeking help could constitute losing face. ${ }^{85}$

Mr. Richard John Egan, Board Member, Treasurer, and Spokesman for the Coalition for the Defense of Human Life, noted the phrase "vulnerable" is applicable to more than just the teenage population. ${ }^{86}$ The phrase should also encompass any person who has a suicidal predisposition, ${ }^{87}$ because of either depression or other stressful events in life, and access to a carriage service. ${ }^{88}$

The government contends that the Bill is consistent with research showing that one of the most effective ways to reduce suicide is to limit people's access to suicide methods or pro-suicide counseling. ${ }^{89}$

\section{The History of the Criminal Code Amendment (Suicide Related Material Offenses) Act 2005}

The Criminal Code Amendment (Suicide Related Material Offenses) Act 2005 was originally contained within the Crimes Legislation Amendment (Telecommunications Offenses and Other Measures) Bill 2004. ${ }^{90}$ This Bill was an omnibus of offenses, including offenses related to child pornography and internet grooming of minors for sexual purposes. ${ }^{91}$ After introduction to the Senate, the Federal Government extracted the suicide-related offenses from that Bill $^{92}$ and reintroduced them, without changes, as the Criminal Code Amendment (Suicide Related Material Offenses) Bill 2004 in August 2004. ${ }^{93}$ Parliament could not review the Bill before its prorogation; consequently, it postponed the Bill until 2005..$^{94}$

Parliament created the Bill to work in conjunction with the Australian

85. Provisions of the Criminal Code Amendment, supra note 16, at 39 (citing Thompson, supra note 83); see also Dutton, supra note 3.

86. Reference: Criminal Code Amendment (Suicide Related Material Offenses) Bill, supra note 67, at L\&C 4. The Coalition for the Defense of Human Life is located in Perth, Australia. Letter from the Coalition for the Defense of Human Life to the Senate Legal and Constitutional Committee, available at http://www.aph.gov.au/senate/committee/legcon_ctte/suicide/submissions/sub09.pdf, (last visited May 23, 2008). The Coalition submitted a response to Parliament in support of the Suicide Related Material Offenses Bill 2005. Id.

87. Carriage services include the internet, email, mobile and fixed telephones, faxes, radio, and television. Criminal Code Amendment (Suicide Related Material Offenses) Bill, 2005, (Austl).

88. Reference: Criminal Code Amendment (Suicide Related Material Offenses) Bill, supra note 67 , at L\&C 4.

89. Provisions of the Criminal Code Amendment, supra note 16, at 36 (citing D. Gunnell and S. Frankel, Prevention of Suicide: Aspirations and Evidence, 308 BRIT. MED. J. 1227 (1994)).

90. Criminal Code Amendment (Suicide Related Material Offenses) Bill, 2005 (Austl.). See also Provisions of the Criminal Code Amendment, supra note 16, § 1.2.

91. Criminal Code Amendment (Suicide Related Material Offenses) Act, 2005 (Austl.).

92. Provisions of the Criminal Code Amendment, supra note 16, § 1.2.

93. Criminal Code Amendment (Suicide Related Material Offenses) Act, 2005 (Austl.); see also Provisions of the Criminal Code Amendment, supra note 16, $\S 1.3$.

94. Provisions of the Criminal Code Amendment, supra note 16, $\$ 1.3$. 
Customs (Prohibited Imports) Regulations 1956. ${ }^{95}$ This regulation directly prohibits "the importation of a device designed or customized to be used by a person to commit suicide, or to be used by a person to assist another person to commit suicide." 96 Moreover, the regulation absolutely prohibits documents promoting suicide kits, counseling or inciting a person to use a suicide kit, or instructing a person to commit suicide using one of the suicide kits. ${ }^{97}$ After the passage of the regulation and the birth of cyberspace, the Internet was used to post information on how to make suicide kits to circumvent the Customs (Prohibited Imports) Regulations. ${ }^{98}$ The Suicide Related Material Offenses Act intends to criminalize the use of the Internet to inform others on methods of suicide inconsistent with Australia's regulations. ${ }^{99}$

In March 2005, Parliament called for submissions to inquiry of the Bill in a national newspaper, The Australian. ${ }^{100}$ Parliament received thirty-one submissions, twenty-one of which were in response to the 2004 Bill but were allowed to be viewed as submissions for the $2005 \mathrm{Bill}^{101}$

The submissions came from a variety of places: the Voluntary Euthanasia Society of Tasmania, ${ }^{102}$ Coalition for the Defense of Human Life, ${ }^{103}$ Gilbert + Tobin Centre of Public Law, ${ }^{104}$ the Australian Civil Liberties Union, ${ }^{105}$ physicians, ${ }^{106}$ a number of Australian citizens, ${ }^{107}$ and many more. Even though some submissions expressed support for the Bill and others expressed disdain, the majority of the submissions objected to the Bill in its entirety. ${ }^{108}$

95. See id. § 3.3(1); see also Calson Analytics, supra note 4.

96. Customs (Prohibited Imports) Regulations, 1956, § 3AA(1) (Cth).

97. Customs (Prohibited Imports) Regulations $\S \S 3 A A(2)(a-c)$.

98. Provisions of the Criminal Code Amendment, supra note 16, § 3.3(1) (quoting Submission 31 (the confidential submission) at 5).

99. Provisions of the Criminal Code Amendment, supra note 16, § 3.3(1).

100. Id. $\S 1.5$.

101. Id. $\$ 1.6$.

102. Letter from Jocelyn Head to the Senate Legal and Constitutional Committee, supra note 3.

103. Letter from the Coalition for the Defense of Human Life to the Senate Legal and Constitutional Committee, supra note 86.

104. Letter from George Williams, Faculty of Law, Gilbert + Tobin Centre of Public Law, to the Senate Legal and Constitutional Committee, (Aug. 26, 2004), available at http://www.aph.gov.au/senate/committee/legcon_ctte/suicide/submissions/sub21.pdf.

105. Letter from Geoff Muirden, Research Officer, the Australian Civil Liberties Union, to

the Senate Legal and Constitutional Committee, available at http://www.aph.gov.au/senate/committee/legcon_ctte/suicide/submissions/sub24.pdf (last visited May 23, 2008).

106. See Letter from Dr. David M. Gawler to the Senate Legal and Constitutional Committee, supra note 80.

107. See Letter from Gillian Walker to the Senate Legal and Constitutional Committee, available http://www.aph.gov.au/senate/committee/legcon_ctte/suicide/submissions/sub03.pdf (last visited May 23, 2008).

108. Provisions of the Criminal Code Amendment, supra note $16, \S 3.1$. 
To comply with the requests and substantive changes suggested by the public, Parliament made changes to two provisions of the original Bill and added two sections to the new Bill. ${ }^{109}$ Under the 2004 Bill, a violation of Section 474.29A only occurred if a person used a carriage service to publish suicide related material which "directly or indirectly counsel[ed] or incite[d] suicide" and the person either intended the material, through his doing or another's, to incite or cause suicide. ${ }^{110}$ The 2005 Bill recognizes such use of a carriage service with suicide related material does not need to cause an actual suicide; instead, a violation only occurs under Section 474.29A if such material "directly or indirectly counsels or incites committing or attempting to commit suicide." 111

Similarly, the 2004 Bill made it a crime for a person to possess, produce, supply, or obtain material that directly or indirectly counsels or incites actual suicide under Section 474.29B. ${ }^{12}$ The Suicide Related Material Offenses Bill 2005 now makes it illegal for a person to possess, produce, obtain or supply material that "directly or indirectly counsels or incites committing or attempting to commit suicide." 13

The third change from the 2004 Bill to the 2005 Bill was the addition of Section $474.29(\mathrm{~A})(3)-(4) .{ }^{114}$ Both of these sections clarify a person is not guilty of an offense under Section 474.29(A)(1)-(2) merely because the person used a carriage device to:

(a) engage in public discussion or debate about euthanasia or suicide; or

(b) advocate reform of the law relating to euthanasia or suicide;

If the person does not:

(c) intend to use the material concerned to counsel or incite committing or attempting to commit suicide; or

(d) intend that the material concerned be used by another person to counsel or incite committing or attempting to commit suicide. ${ }^{115}$

Parliament added this language into the Suicide Related Materials Bill 2005 in response to complaints that the Bill impinged on freedom of expression. ${ }^{116}$ In their submission to the inquiry, Festival of Light Australia noted that the Commonwealth Constitution contains an implicit right to

109. Criminal Code Amendment (Suicide Related Material Offenses) Bill, 2005, (Austl).

110. Criminal Code Amendment (Suicide Related Material Offenses) Bill, 2004, (Austl.).

111. Criminal Code Amendment (Suicide Related Material Offenses) Act, 2005 (Austl.). (emphasis added).

112. Criminal Code Amendment (Suicide Related Material Offenses) Bill, 2004, § 474.31 (Austl.).

113. Id. $\S 474.29 \mathrm{~B}(\mathrm{~b})(\mathrm{i})$.

114. Criminal Code Amendment (Suicide Related Material Offenses) Bill, 2005 (Austl.)

115. Id.

116. See Provisions of the Criminal Code Amendment, supra note $16, \S 3.26$. 
freedom of political expression. ${ }^{117}$ Because the Suicide Related Material Offenses Bill allows for continued political debate on euthanasia, ${ }^{118}$ and the Bill only criminalizes speech that incites or encourages others to commit or attempt to commit suicide, it does not impinge on freedom of expression because freedom of speech has never given an unqualified right to do harm. ${ }^{119}$

With these provisions accommodating as many inquiries as possible, the Suicide Related Material Offenses Bill 2005 received Royal Assent ${ }^{120}$ on July 6, $2005 .^{121}$ It became effective January 6, 2006. ${ }^{122}$

The Suicide Related Material Offenses Bill 2005 is an amendment to Australia's Criminal Code Act of 1995. ${ }^{123}$ Schedule 1 of the Bill states the Amendment should be inserted into the Criminal Code after Section 474.29, ${ }^{124}$ the Telecommunications Offenses section of the Criminal Code. ${ }^{125}$

\section{Analysis of the Criminal Code Amendment (Suicide Related Material Offenses) Act 2005}

At its simplest, the Suicide Related Material Offenses Bill prohibits using carriage services such as the "internet, email, telephones, fax machines, radios, or television" "26 with the intention of counseling or inciting actual or attempted suicide and "promoting or providing instruction on a particular method of suicide." 127 Possessing, controlling, producing, supplying, or obtaining material for use on a carriage service that can either directly or indirectly counsel or incite actual or attempted suicide, or promote a particular method of suicide is also illegal under the new legislation. ${ }^{28}$ The fines for these offenses

117. Letter from Festival of Light to Senate Legal Constitutional Committee, supra note 66, at 1 (quoting Australian Capital Television v. Commonwealth (1992) 177 CLR 106, 135, per Mason CJ). Festival of Light is a Christian ministry in Australia; its main goal is to promote "true family values in the light of the wisdom of God." Festival of Light, Welcome to Festival of Light, http://www.fol.org.au/welcome/index.html (last visited May 23, 2008).

118. Criminal Code Amendment (Suicide Related Material Offenses) Act, 2005, § 474.29A(3) (Austl.). The Bill states a person is not guilty of an offense if one uses a carriage device to "(a) engage in public discussion or debate about euthanasia or suicide, or (b) advocate reform of the law relating to euthanasia or suicide." $I d$. This holds true as long as the person is not intending to use said material to counsel or incite suicide. Id.

119. Letter from Festival of Light Australia to Senate Legal and Constitutional Committee, supra note 66.

120. Royal assent is "the last stage in the process by which a Bill becomes an Act; the Governor, representing the Queen, gives it formal approval." Parliament of Victoria, $A$ Parliament Glossary, http://www.parliament.vic.gov.au/gloss.html (last visited May 22, 2008).

121. Criminal Code Amendment (Suicide Related Material Offenses) Act, 2005 (Austl.).

122. Id.

123. Id.; see also Provisions of the Criminal Code Amendment, supra note 16, §1.4.

124. Criminal Code Amendment (Suicide Related Material Offenses) Act, 2005, sched. 1 (Austl.).

125. Criminal Code Act, 1995, (Austr.)

126. Provisions of the Criminal Code Amendment, supra note 16, at 33.

127. Id.

128. Criminal Code Amendment (Suicide Related Material Offenses) Act, 2005, § 474.29B 
are exorbitantly high: up to $\$ 110,000$ AUD (Australian Dollars) for individuals and up to $\$ 500,000$ AUD for organizations. ${ }^{129}$

However, much debate occurs regarding the statutory interpretation of this $\mathrm{Act}^{130}$ and its legal ramifications for free speech, both for political communication ${ }^{131}$ and personal communication. ${ }^{132}$, ${ }^{133}$ whether the Act will be able to achieve its aims, ${ }^{134}$ and, finally, whether the Act is even necessary. ${ }^{135}$

\section{i. Parliament's Power to Regulate the Internet}

Parliament cannot subject a person to proposed offenses if it does not have the constitutional power to enact a law. ${ }^{136}$ Consequently, the threshold question is whether the Commonwealth had power, derived from the Australian Constitution, to enact the Suicide Related Material Offenses Act. If there was no such power, then there can be no such law.

In one of their two submissions regarding the Act, Exit International actually questioned whether the regulations exceeded the Parliament's authority. ${ }^{137}$ The submission points to Section 51 of the Australian Constitution. ${ }^{138}$ Section 51 states that " $[t]$ he Parliament shall ... have power to make laws for the peace, order, and good government of the Commonwealth . . . ."139 Exit International believes the Act goes farther than this limitation because it "will restrict and control the flow of information to many outside of

(Austl.).

129. Barnes, supra note 2.

130. See generally Reference: Criminal Code Amendment, supra note 67 (noting that the Committee asked several witnesses if they felt the wording of the Act, including the use of the words "counsel," "incite," and "directly or indirectly," was too ambiguous or problematic).

131. Letter from Jocelyn Head to the Senate Legal and Constitutional Committee, supra note 3; Letter from Electronic Frontiers Australia, Inc. to the Senate Legal and Constitutional Committee, supra note 16, §6, art. 23-30.

132. Letter from Electronic Frontiers Australia, Inc. to the Senate Legal and Constitutional Committee, supra note 16, $\$ 7$, art. 31-34; Reference: Criminal Code Amendment, supra note 67, at L\&C 15-17.

133. Letter from Jocelyn Head to the Senate Legal and Constitutional Committee, supra note 3. Sandra Kanck, MLC, Address to South Australian Legislative Counsel (Aug. 30, 2006) (on file with the author).

134. Provisions of the Criminal Code Amendment, supra note 16, at 8.

135. Letter from Electronic Frontiers Australia, Inc. to the Senate Legal and Constitutional Committee, supra note $16, \S 12$, art. 79 . The Act may not be necessary because the Australian Criminal Code already contains a law imposing criminal penalties for the use of a carriage service to violate a serious offense under Australian law. Id.

136. Crimes Legislation Amendment (Telecommunications Offenses and Other Measures) Bill, 2004 (Austl.).

137. Letter from Exit International to the Senate Legal and Constitutional Committee (Aug. 19 , 2004), available

http://www.aph.gov.au/senate/committee/legcon_ctte/suicide/submissions/sub16a.pdf. Exit International is a pro-choice voluntary euthanasia/assisted suicide organization led by Dr. Philip Nitschke. Exit International, http://www.exitintemational.net/ (last visited May 23, 2008).

138. Letter from Exit International to the Senate Legal and Constitutional Committee, supra note 137.

139. AUSTL. CONST. pt. V, $\S 51$. 
the jurisdiction" of Australia and affect their lives. ${ }^{140}$

The Crimes Legislation Amendment (Telecommunications Offenses and Other Measures) Bill 2004 lays out the constitutionally derived power for the Commonwealth to regulate telecommunications, including electronic telecommunications such as the internet. ${ }^{141}$ Section $51(5)$ of the Constitution gives Parliament the power to make laws for the Commonwealth with respect to "postal, telegraphic, telephonic, and other like services."142 The High Court of Australia has interpreted the phrase "other like services" to include both radio and television, and in 1935, the High Court found that the common characteristic of these services is "they are . . . communication services."143 The High Court also indicated the phrase "other like services" includes new forms of communication to be discovered in the future. ${ }^{144}$ Therefore, new services, such as the internet, fall under the authority of Parliament to regulate. $^{145}$

\section{ii. Definitional Issues with the Act}

In a hearing for the Senate Legal and Constitutional Legislation Committee in reference to the Act, Irene Graham, Executive Director of Electronic Frontiers Australia, Inc., stated that her organization was concerned the "actual wording of most of the offences is insufficiently defined for people to generally be able to understand where the line is drawn." 146 Therefore, it is important to analyze the actual meaning behind the words used, such as 'material,' 'incite,' 'counsel,' and 'indirectly,' to construct the regulation.

a. What constitutes "material" under the Act?

The name of the Act and Sections 474.29A and 474.29B all include the word "material" and the Act directly regulates the use of said material when

140. Letter from Exit International to the Senate Legal and Constitutional Committee, supra note 137. However, Ms. Graham of Electronic Frontiers Australia, Inc. stated in the hearing for the Senate Legal and Constitutional Legislation Committee that this legislation would "not have any effect on international communication except to the extent of criminalising Australians that [sic] are participating in any such international communication." Reference: Criminal Code Amendment, supra note 67, at L\&C 30.

141. Crimes Legislation Amendment (Telecommunications Offenses and Other Measures) Bill, 2004 (Austl.)

Since the Suicide Related Material Offenses Act was originally included in this Bill, it is helpful to look to the Bills Digest in order to discover the groundwork for the regulation. See Suicide Related Material Offenses Bills Digest, supra note 87.

142. AUSTL. CONST. § 51(5).

143. Crimes Legislation Amendment (Telecommunications Offenses and Other Measures) Bill, 2004 (Austl.)

144. Crimes Legislation Amendment (Telecommunications Offenses and Other Measures) Bill.

145. Id.

146. Reference: Criminal Code Amendment, supra note 67, at L\&C 30. 
being transferred over a carriage service or possession of material with the intent to transfer the material over a carriage service. ${ }^{147}$ In order to ensure compliance with the regulation, it is important to understand to what the word material refers. ${ }^{148}$

The word 'material' as defined in the Criminal Code Act 1995 refers to "material in any form, or combination of forms, capable of constituting a communication.", 'Suicide promotion material' is defined in the Criminal Code Act 1995 defines "suicide promotion material" as "material that, directly or indirectly: (a) promotes, counsels, or incites suicide, or (b) provides instruction on how to commit suicide."150 Therefore, any material that constitutes communication that directly or indirectly counsels or incites suicide or provides instruction on suicide constitutes material which violates the Act. ${ }^{151}$

\section{b. Interpretation of 'Counsel' and 'Incite'}

Several times the Suicide Related Material Offenses Act refers to the use of material to 'counsel' or 'incite' committing or attempting to commit suicide. $^{152}$ Several critics of the Act have expressed disdain over the ambiguous definitions of both 'counsel' and 'incite., 153

In the submission by Electronic Frontiers Australia (EFA), Irene Graham noted the Model Criminal Code Committee has expressed concern over the use of 'incite' in criminal offenses. ${ }^{154}$ This concern stems from the fear that courts will interpret 'incite' "“as only requiring causing rather than advocating the offence.", 155 If this interpretation is adopted by the courts, then the Act could "criminalize journalists and ordinary individuals reporting on and discussing

147. See Criminal Code Amendment (Suicide Related Material Offenses) Act, 2005 (Austl.).

148. See Reference: Criminal Code Amendment, supra note 67.

149. Criminal Code Act, 1995, § 473.1 (Austr.).

150. Id.

151. See Letter from Jocelyn Head to the Senate Legal and Constitutional Committee, supra note 3. Material that would fall under this provision includes material that would provide "advice and assistance in dying for terminally ill patients, at their request," a sentiment that greatly worries voluntary euthanasia programs all over Australia. Id.

152. Criminal Code Amendment (Suicide Related Material Offenses) Act, 2005 (Austl.).

153. See Letter from Electronic Frontiers Australia, Inc. to the Senate Legal and Constitutional Committee, supra note 16. The EFA is a "non-profit national organisation [sic] representing Internet users concerned with on-line rights and freedoms." Id. § 14; see also Letter from Jocelyn Head to the Senate Legal and Constitutional Committee, supra note 3; Letter from South Australian Voluntary Euthanasia Society to the Senate Legal and Constitutional Committee, available at http://www.aph.gov.au/senate/committee/legcon_ctte/suicide/submissions/sub10.pdf (last visited May 23, 2007).

154. Letter from Electronic Frontiers Australia, Inc. to the Senate Legal and Constitutional Committee, supra note $16, \S 8$, art. 36 .

155. Id. 
suicide" ${ }^{\text {156 }}$ because research has shown even media discussion causes an increase in suicide rates. ${ }^{157}$

In response to such concerns, Geoffrey Gray, a representative for the Attorney-General's Department, pointed out that.$^{158}$ The Criminal Code Act states that to be guilty of incitement a person has to do more than just cause the offense; rather the person must "urge[] the commission of an offence" to be guilty of incitement. ${ }^{159}$ Therefore, incitement requires intent for an event to be carried out instead of a mere coincidence. ${ }^{160}$

The use of 'counsels' was also troublesome because it was not defined in the Act. ${ }^{161}$ The EFA found this phrase to be "dangerously broad."162 The EFA submissions recognized that ${ }^{163}$ For example, counseling may mean listening, giving advice, or providing direction. ${ }^{164}$ Euthanasia societies across Australia worry this legislation will interfere with or criminalize the positive counseling which can discourage individuals from committing or attempting to commit suicide. ${ }^{165}$

- In addressing these concerns, the Attorney General's office recognized that when one actively counsels another to commit suicide rather than dissuading one from committing suicide, then the counseling would be a violation under the regulation. ${ }^{166}$ However, the Attorney General also recognized the term counseling is a "legally used concept which appears widely throughout Commonwealth law or Australian law."167 It is not to be confused with counseling in the medical sense, but, instead, seen as "encouraging the person with an intent to bring about a result."

Therefore, the term 'counsel' should be read narrowly and defined as the

156. Id. $\$ 10$, art. 59.

157. Id. $\S .10$, art. 58. For example, "[h]igher rates of suicide by a particular method such as burning or anti-freeze poisoning" followed reports in newspapers documenting this particular method of suicide. $I d$.

158. Reference: Criminal Code Amendment, supra note 64, at L\&C 36.

159. Criminal Code Act, 1995, \& 11.4 (Austr.).

160. See Criminal Code Act $\$ 11.4$.

161. Letter from Electronic Frontiers Australia, Inc. to the Senate Legal and Constitutional Committee, supra note $16, \S 10$, art. 60 .

162. Id. art. 61.

163. Id. art. 60.

164. See id.; see also Letter from Jocelyn Head to the Senate Legal and Constitutional Committee, supra note 3.

165. Letter from South Australian Voluntary Euthanasia Society to the Senate Legal and Constitutional Committee, supra note 153.

166. See Reference: Criminal Code Amendment, supra note 67, at L\&C at 37-39.

167. Id. at 38. The submission notes that the phrase "counsels or incites" is used in the Customs Regulation that the Suicide Related Material Offenses Act compliments. Id. at L\&C 29. Also, the phrase is used in State and Territory laws regulating assisted suicide. Id.

168. Id. at L\&C 38. The Attorney General's Department noted this regulation would not criminalize the services provided by suicide helplines, such as Lifeline, when the aim is to counsel those out of committing suicide. Letter from the Attorney General's Department to the Senate Legal and Constitutional Legislation Committee (Apr. 14, 2005), available at http://www.aph.gov.au/senate/committee/legcon_ctte/suicide/submissions/sub32.pdf. 
intent of urging another to commit suicide. ${ }^{169}$ To dispel fears that the word 'counsel' may interfere with counseling in the medical sense, the Committee added the word 'committing' into the regulations; ${ }^{170}$ the phrase now reads "counsels or incites committing or attempting to commit suicide."171 The goal of this addition was to "put beyond doubt that counseling about suicide would not be captured unless the person encouraged or gave advice on the actual commission of a suicide."172

\section{c. What is meant by 'indirectly'?}

Voluntary euthanasia societies also complained that the use of the term 'indirectly' in the Act ran similar risks to the use of the term 'counsel., 173 These societies feared they could face criminal prosecution for the dissemination of information that is not intended to promote suicide or incite people to commit suicide, but can, at times, have the reverse effect on those who read it. ${ }^{174}$ Therefore, this phrasing has the possibility to criminalize valid information because it could be interpreted as indirectly counseling suicide. ${ }^{175}$

Legislators, however, did not write "indirectly" into the regulation to catch offenses about which the voluntary euthanasia societies are concerned. ${ }^{176}$ The Attorney General's department explains the use of 'indirectly' as a "commonly used drafting device in criminal offenses that covers a situation where a person does not actually carry out the prescribed conduct in exact words but does so by necessary implication." indirectly under the Suicide Related Materials Act, the person in possession of material must still intend the material to be used to counsel or incite suicide, or to promote a method of suicide, or be used by another to instruct one how to commit suicide. ${ }^{178}$ Those societies disseminating information with the intent to discourage suicide will not be found to have indirectly counseled, incited, or promoted suicide. $^{179}$

169. Letter from the Attorney General's Department to the Senate Legal and Constitutional Committee, supra note 168.

170. Id.

171. Criminal Code Amendment (Suicide Related Material Offenses) Act, 2005, § 474.29A(1)(b)-474.29A(1)(b)(i) (Austl.).

172. Letter from the Attorney General's Department to the Senate Legal and Constitutional Committee, supra note 168.

173. See Letter from South Australian Voluntary Euthanasia Society to the Senate Legal and Constitutional Committee, supra note 153.

174. Id.

175. Letter from Electronic Frontiers Australia, Inc. to the Senate Legal and Constitutional Committee, supra note $16, \S 10$, art. 62 .

176. Letter from the Attorney General's Department to the Senate Legal and Constitutional Committee, supra note 168.

177. Id.

178. Id.

179. See id. 


\section{Recklessness}

\section{d. Fault Elements: Intention and}

Recklessness is the fault element regarding whether an offense has been committed. ${ }^{180}$ The Criminal Code Act Section 5.4 defines the fault element. ${ }^{181}$ A person is reckless if "he or she is aware of a substantial risk that the circumstance exists or will exist; and, having regard to the circumstances known to him or her, it is unjustifiable to take the risk." 182 Even if the court finds one to have acted recklessly in his or her actions, however, he or she has not necessarily committed a criminal offense under the Act. ${ }^{183}$

The Act still requires a person to intend another to use the relevant material to commit or attempt to commit suicide, promote a particular method of suicide, or for another person to use the material to counsel or incite suicide. ${ }^{184}$ "Without that intention, no offence would be committed." 185 This intent requirement also protects debate about law reform concerning euthanasia because such debate would not have the requisite intention. ${ }^{186}$

Intent, as defined by the Criminal Code Section 5.2, however, states, "a person has intention with respect to a result if he or she means to bring it about or is aware that it will occur in the ordinary course of events." 187 Arguably, an individual who posts information on the internet would be aware it could counsel or incite another to commit suicide. ${ }^{188}$ Therefore, "an offence may be committed even if" the information is focused on law reform. ${ }^{189}$ The difficulty in proving a person lacked the requisite intent to incite or counsel another to commit suicide because he or she was participating in public discussion on law reform would place a high burden on an innocent party. ${ }^{190}$ Parliament must rely on the catch-all added to the Suicide Related Material Offenses Act Section 474.29A(3)-(4) that states material intended for public discussion or debate or to advocate law reform is not a violation of the Act. ${ }^{191}$

180. Letter from Jocelyn Head to the Senate Legal and Constitutional Committee, supra note 3 .

181. Criminal Code Act, 1995, $\$ 5.4$ (1) (Austr.).

182. Criminal Code Act, 1995, $\$ 5.4$ (1) (Austrl.)

183. Letter from the Attorney General's Department to the Senate Legal and Constitutional Committee, supra note 168.

184. Id.

185. Id.

186. Letter from Voluntary Euthanaisa Society of Victoria to the Senate Legal and Constitutional Committee, available

at http://www.aph.gov.au/senate/committee/legcon_ctte/suicide/submissions/sub1 1.pdf (last visited May 23, 2008).

187. Criminal Code Act, $1995, \S 5.2(3)$ (Austr.).

188. Letter from George Williams to the Senate Legal and Constitutional Committee, supra note 104.

189. Id.

190. Letter from Voluntary Euthanasia Society of Victoria to the Senate Legal and Constitutional Committee, supra note 186.

191. Criminal Code Amendment (Suicide Related Material Offenses) Act, 2005 (Austl.). 


\section{iii. Is the Act Unnecessary Because Existing Legislation Regulates the Activity Being Criminalized?}

The EFA argued that this legislation was unnecessary because existing legislation already criminalizes using a carriage service in this manner. ${ }^{192}$ The Crimes Legislation Amendment (Telecommunications Offenses and Other Measures) Bill (No.2) 2004, which went into effect on March 1, 2005, makes it a criminal offense to use a carriage service to commit a serious offense. ${ }^{193}$ It defines a serious offense as "an offence against a law of the Commonwealth, a State or a Territory that is punishable by imprisonment for a period of 5 or more years or for life." 194 The assisted-suicide laws of the Australian territories are included as serious offenses under this section. ${ }^{195}$ Therefore, it is already a criminal offense to use a carriage service to aid or abet another to commit suicide. ${ }^{196}$

The EFA further points out that the penalty for violating Section $\mathbf{4 7 4 . 1 4}$ is "equal to the maximum penalty for the serious offence the person commits or is intending to commit."197 The penalties for violating the Suicide Related Material Offenses Act, however, are monetary penalties. ${ }^{198}$ The EFA expressed its concern over which offense the prosecution would charge a person who used a carriage service to counsel or incite suicide, and whether to charge that person with two Commonwealth offenses. ${ }^{199}$

While it is true legislation covering the use of carriage services to commit serious offenses in Australian States and Territories exists, the existing legislation does not cover lesser offenses contained in the Act. ${ }^{200}$ Parliament and the Attorney General contend the Suicide Related Material Offenses Act "[goes] beyond the ambit of State and Territory offences in this area by covering material that promotes or provides instruction on a particular method of committing suicide." ${ }^{201}$ Another difference between the two Acts is the

There is much debate whether this catch-all will actually be successful in protecting debate on law reform. See generally Reference: Criminal Code Amendment, supra note 67.

192. Letter from Electronic Frontiers Australia, Inc. to the Senate Legal and Constitutional Committee, supra note $16, \S 4$, art. 12-13.

193. Id. § 4, art. 14.

194. Id.

195. Id. Some of the assisted suicide statutes have penalties of up to life imprisonment. E.g. Criminal Code, $1899, \S 311$ (Queensl.). Some stipulate a penalty for five or ten years. E.g. Crimes Act, 1900, § 31C (NSW).

196. Letter from Electronic Frontiers Australia, Inc. to the Senate Legal and Constitutional Committee, supra note $15, \S 4$, art. 16.

197. Id. \& 4, art 17.

198. Criminal Code Amendment (Suicide Related Material Offenses) Act, 2005 (Austl.). The monetary penalties for an individual who violates the Act can be up to $\$ 110,000$ (AUD) and up to $\$ 500,000$ for businesses which violate the offense. Barnes, supra note 2 .

199. Letter from Electronic Frontiers Australia, Inc. to the Senate Legal and Constitutional Committee, supra note $16, \S 4$, art. 18.

200. Reference: Criminal Code Amendment, supra note 67, at L\&C 3.

201. Letter from the Attorney General's Department to the Senate Legal and Constitutional Committee, supra note 168. 
Suicide Related Material Offenses Act criminalizes material put on the internet which encourages suicide, but has not yet counseled or incited a person to commit suicide. ${ }^{202}$ Under the Crimes Legislation Amendment (Telecommunications Offenses and Other Measures) Bill (No.2) 2004, the prosecution would have to show the material had actually aided or abetted another to commit suicide. ${ }^{203}$

A third reason presented by the government in enacting a separate law is purely policy based. This policy based reason recognizes the difficulty in comprehending the Crimes Legislation Amendment (Telecommunications Offenses and Other Measures) Bill (No.2) 2004. ${ }^{204}$ Therefore, if Parliament wants to make it illegal to use carriage services to counsel or incite suicide, share methods of suicide, or make material available for others to use to encourage suicide, then an Act that explicitly criminalizes such conduct should exist in the Criminal Code. ${ }^{205}$

\section{iv. Imposition of Freedom of Communication}

Another legal roadblock that the Suicide Related Material Offenses Act had to overcome was the effect on freedom of communication. ${ }^{206}$ This freedom of communication covers three separate areas: freedom of political communication, ${ }^{207}$ freedom of personal and private levels of communication, ${ }^{208}$ and the impact on access to personal information. ${ }^{209}$

\section{a. Freedom of Political Communication}

Assisted-suicide is a major topic of debate in almost every civilization. ${ }^{210}$ In Australia, seventy-five percent of the population polled in recent years approve of legalizing assisted suicide in their territories or nation. ${ }^{211}$ Many critics fear this new law will chill debate on this topic and keep laws legalizing euthanasia from becoming a reality. ${ }^{212}$ In an attempt to calm these fears,

202. Reference: Criminal Code Amendment, supra note 67, at L\&C 39 .

203. Id. at L\&C 29.

204. Id. at L\&C 40.

205. Id.

206. See generally id.

207. See generally id.

208. Id. at L\&C 15-17. See also Letter from George Williams to the Senate Legal and Constitutional Committee, supra note 104.

209. See Letter from Electronic Frontiers Australia, Inc. to the Senate Legal and Constitutional Committee, supra note 16.

210. See supra, note 1 and accompanying text.

211. Letter from Anthony and Beryl Saclier to the Senate Legislation Senate Legal and Constitutional Legislation Committee, available at http://www.aph.gov.au/senate/committee/legcon_ctte/suicide/submissions/sub08.pdf (last visited May 23, 2008).

212. Letter from New South Wales Council for Civil Liberties to the Senate Legal and Constitutional Committee (Apr. 4, 2004), available at 
Parliament amended the 2004 Bill to include two sections which protected material used for public discussion of law reform. ${ }^{213}$

Australia's High Court has established an implied freedom of political communication in the Australian Constitution. ${ }^{214}$ The High Court of Australia defined political communication as including "discussions of issues of public affairs, expressions critical of government policies and institutions, and criticism of candidates for election." ${ }^{215}$ No one contends that debate over assisted-suicide and law reform over euthanasia fails to fall under political communication. ${ }^{216}$ The question that remains is whether the Suicide Related Materials Offenses Act violates this implied freedom of communication. ${ }^{217}$

Even though the parliament added catchall provisions to the Suicide Related Material Offenses Act, the existence of such a criminal statute can still chill public debate because "advocates will not be certain when their speech is lawful and when it is not." because these clauses still rely upon the intent of the person. ${ }^{219}$ Therefore, if one can show an ulterior motive for the statement, such as incitement to commit suicide, then the defense of public debate on law reform would fail. ${ }^{220}$ In addition, the catchall is worthless because it does not define "what may or may not be communicated without risking criminal prosecution."221 If Parliament finds it necessary to explicitly spell out this offense to the public in the Criminal Code, ${ }^{222}$ perhaps Parliment should consider spelling out what may or may not be communicated through the use of a carriage service. ${ }^{223}$ Also, because the implied freedom of political communication has not been welldefined by the High Court, it is arguable whether the High Court cannot expect

http://www.aph.gov.au/senate/committee/legcon_ctte/suicide/submissions/sub27.pdf.

213. Suicide Related Material Offenses Bills Digest, supra note 87.

214. Katharine Gelber, The Scope of the Implied Freedom of Political Communication in Australia, Refereed paper presented to the Jubilee conference of the Australasian Political Studies Association Australian National University (Oct. 2002), in Papers from the Jubilee Conference of the Australasian Political Studies Association,

available at http://www.arts.anu.edu.au/sss/apsa/Papers/gelber.pdf. The justices on the High Court established this implied freedom "because the Australian Constitution enshrined a system of representative government" and there is a need for freedom of communication over political matters. Id.at 2.

215. Id. at 3 .

216. See generally Reference: Criminal Code Amendment, supra note 67.

217. Id. at L\&C 15-17.

218. Letter from New South Wales Council for Civil Liberties to the Senate Legal and Constitutional Committee, supra note 212. This submission queries whether a question written by a euthanasia advocate stating " " $[w]$ hy should we not be able to tell people that the most human euthanasia option is [some specified option]..." would be caught under the Act or if the defense of political debate would save the advocate from prosecution. Id.

219. Letter from Electronic Frontiers Australia, Inc. to the Senate Legal and Constitutional Committee, supra note 16, §6, art. 25.

220. Id.

221. Id. $\S 6$, art. 28.

222. Reference: Criminal Code Amendment, supra note 67, at L\&C 40.

223. See Letter from Electronic Frontiers Australia, Inc. to the Senate Legal and Constitutional Committee, supra note $16, \S 6$, art. 30. 
the public to know whether its communication is covered or whether it is a violation of the Act. ${ }^{224}$

In a speech made before the Southern Australian Legislative Council, Sandra Kanck, a Democrat Member of the Legislative Council in the South Australian Parliament, ${ }^{225}$ attacked this "asinine law" because it encroached on freedom of speech. ${ }^{226}$ She recognized that her speech, which should have been made part of the Hansard record, ${ }^{227}$ would not be allowed to appear on Parliament's websites because of her references to particular methods of suicide. ${ }^{228}$ In the end, the South Australian Parliament did move to have the speech banned from the website. ${ }^{229}$ However, Exit International, a proeuthanasia organization, posted the speech on its website that was hosted in New Zealand, and therefore, was not subject to the Suicide Related Material Offenses Act. ${ }^{230}$

In response to the concerns over freedom of political communication, the government relied heavily on the intent requirement in order for a crime to be committed. $^{231}$ The government contended that if a person was truly debating over euthanasia and law reform, then he or she would have lacked the requisite intent that the material be used to incite or counsel suicide or violate the Act in any other way. ${ }^{232}$ Also, the government found that if there were any ambiguities in the provisions that the courts would read and construct the ambiguities in favor of the defendants, or those who made the speech. ${ }^{233}$ Therefore, as the government sees it, the regulation did not affect political communication. ${ }^{234}$

224. Id. § 6, art. 30.

225. Sandra Kanck: Leader SA Democrats, http://sa.democrats.org.au/people/Sandra\%20Kanck/SKpolitical.htm (last visited May 22, 2008).

226. Kanck, supra note 133.

227. The Hansard record is the written record of parliamentary debates. Parliament of Victoria, supra note 120.

228. Kanck, supra note 133 . The last half of her speech detailed specific methods of suicide, including the plastic bag method, the use of Nembutal and how to obtain it, and traveling to Switzerland to receive medication that will end one's life. Id.

229. Press Release, Exit International, Censored Kanck Speech to be Listed, Sept. 4, 2006, available at http://www.scoop.co.nz/stories/WO0609/S00061.htm.

230. Id.

231. See Letter from the Attorney General's Department to the Senate Legal and Constitutional Committee, supra note 168. See also Reference: Criminal Code Amendment, supra note 67 , at L\&C $36-50$.

232. Letter from the Attorney General's Department to the Senate Legal and Constitutional Committee, supra note 168.

233. Reference: Criminal Code Amendment, supra note 67.

234. Id. 


\section{b. $\quad$ Freedom of Personal and Private Levels of}

\section{Communication}

The submissions also expressed concern regarding how the Act interferes with the personal and private communications over the telephone or email that may occur, for example, between doctors and patients or between family members. ${ }^{235}$ This public policy argument called for a "reasonable right to be able to openly communicate with each other about what we would describe as end of life options. ${ }^{\text {"236 }}$ Many worried about the impact this Act would have on those who were seriously or terminally ill and looking for solutions on how to end their pain. ${ }^{237}$

Parliament contended it did not create this legislation to interfere with personal and private conversations; ${ }^{238}$ however, "[i]f a person was to incite another person to commit suicide, whether they were to do it by direct speech, by telephone or by email, that would be caught by the existing offences under state law." ${ }^{239}$ Parliament instituted this Act to protect vulnerable people, ${ }^{240}$ and one can consider those who are terminally ill and looking for help part of the vulnerable population. ${ }^{241}$ Therefore, if a person uses a carriage service to have a personal communication with another, and then counsels or incites him or her to commit suicide, they have violated the Act. ${ }^{242}$

\section{c. Impact on Access to Personal Information}

The EFA further argued in its submission that its disdain for the Act also included its prohibition on possession of information that arguably violates the sections of the Act, such as promoting or providing instruction on a particular method of suicide. ${ }^{243}$ The EFA expressed concern that the law would put a person at risk merely because the person could have intended the information for use by another, even though they had not yet shared the information. ${ }^{244}$

Once again, Parliament addressed this concern by stating an individual

235. Provisions of the Criminal Code Amendment, supra note 16, at 19.

236. Reference: Criminal Code Amendment, supra note 67, at L\&C 17.

237. Letter from George Williams to the Senate Legal and Constitutional Committee, supra note 104

238. Reference: Criminal Code Amendment, supra note 67, at L\&C 37 (noting that imposition on private communications was not part of the direct intention of the legislation).

239. Id.

240. Dutton, supra note 3.

241. Reference: Criminal Code Amendment, supra note 67, at L\&C 4-5.

242. See id. at L\&C 36.

243. Letter from Electronic Frontiers Australia, Inc. to the Senate Legal and Constitutional Committee, supra note $16, \S 9$, art. 54 .

244. Id. $\S 9$, art. 55. "We are of the view that such laws are too prone to selective use to victimise and harass people notwithstanding that the probability of a court finding intent and convicting may be low, that is, there may be no intention to actually prosecute." Id. 
needed to possess the requisite intention in order to violate the act. ${ }^{245}$ For example, possesion of a pamphlet produced with instructions on a particular method of suicide with the intent to place it on the internet or disseminate it through e-mail violates the Act. ${ }^{246}$ Yet, Parliament maintains the law does not make it criminal to possess material if there is no intent to use it for a criminal purpose; therefore, possession of the same pamphlet with no intent to use a carriage device to disseminate it would be legal. ${ }^{247}$

\section{v. Suicide Itself is not an Illegal Act}

Suicide is no longer a criminal act in Australia. ${ }^{248}$ It is unclear whether the Act will prevent one who has chosen to commit suicide from using a carriage service to prepare for his or her death. ${ }^{249}$ For example, it is unclear whether a person has violated the Act if he plans to commit suicide and emails himself notes on the "best or quickest way to commit suicide," or even if he intended to email himself this kind of material. ${ }^{250}$

Apparently, Parliament did not contemplate this loophole, ${ }^{251}$ but its existence could be possible. While some sections of the Act make reference to a person accessing material to intend the material to be used by another person, ${ }^{252}$ there are certainly other possibilities that do not require "another person."253 For example, under Section 474.29A(2), if a person gathered information off of the internet that directly or indirectly provided instruction on a particular method of suicide, and that person intended to use the material to instruct himself on that method, then the statute would arguably be violated. ${ }^{254}$ From a public policy standpoint, the possibility of this prosecution seems wrong since suicide is not a criminal offense and "it is reasonable for any adult to seek information regarding any legal act.",255

245. Letter from the Attorney General's Department to the Senate Legal and Constitutional Committee, supra note 168.

246. Id.

247. Id.

248. Letter from Jocelyn Head to the Senate Legal and Constitutional Committee, supra note 3. See Crimes Act, 1958, \& 6A (Vict.), available at http://www.austlii.edu.au//cgibin/disp.pl/au/legis/vic/consol_act/ca 195882/s6a.html?query=suicide. See also Crimes Act, 1900 , \& 31C (NSW).

249. Letter from New South Wales Council for Civil Liberties to the Senate Legal and Constitutional Committee, supra note 212.

250. Id.

251. See generally Letter from the Attorney General's Department to the Senate Legal and Constitutional Committee, supra note 168.

252. Criminal Code Amendment (Suicide Related Material Offenses) Act, $\$ 474.29 \mathrm{~A}(1)$ (c), 2005 (Austl.).

253. See Criminal Code Amendment (Suicide Related Material Offenses) Act, $\$ 474.29$ A, 2005 (Austl.).

254. Criminal Code Amendment (Suicide Related Material Offenses) Act $\S 474.29 A(2)$.

255. Letter from Jocelyn Head to the Senate Legal and Constitutional Committee, supra note 3. Even if this hypothetical situation occurred, it is questionable whether Parliament would 
Even though it is not illegal to commit suicide, the Senate still feels there is "great value in protecting the general public from people who assist suicide." 256 Therefore, the Senate argued that society could benefit from this Act. ${ }^{257}$ In supporting this Act, Right to Life Australia submitted an analogy to support regulating information on suicide:

Smoking is not illegal but it is generally accepted that because of the harm it causes it is appropriate not to allow it to be advertised. In the same way suicide is not illegal but, due to the harm that promotion of it can cause, we believe it is appropriate for this bill to prohibit promotion of it through carriage services, particularly the internet. ${ }^{258}$

This reasoning suggests that access to material through a carriage service by a person who has the intent to use material for himself or herself would not violate the Act. $^{259}$ If this type of action were a criminal offense, it would violate Parliament's intent in creating the Act. $^{260}$

\section{vi. Other Problems with the Act}

Statutory interpretation and legal implications regarding restriction of expression seem to be the most debated issues with the Suicide Related Material Offenses Act ${ }^{261}$ however, several other criticisms exist. ${ }^{262}$

First, the Act lacks defenses, other than the political discussion on law reform. $^{263}$ Parliament omitted defenses from the Act because Parliament believes no defense should be available to a person if he or she intended to incite or counsel someone to commit suicide. ${ }^{264}$

Secondly, there is debate over whether the Act actually complements the Customs Regulations. ${ }^{265}$ The Customs Regulations only prohibits material that promotes or incites the use of a particular device designed to assist a person in committing suicide. ${ }^{266}$ The Suicide Related Material Offenses Act; however,

actually prosecute the individual contemplating suicide. Australia decriminalized suicide because "there was little value in prosecuting someone who was dead or had attempted suicide. Suicidal people need help, not prosecution." Provisions of the Criminal Code Amendment, supra note 16 , at 38 .

256. Provisions of the Criminal Code Amendment, supra note 16, at 38.

257. Id. at 37.

258. Reference: Criminal Code Amendment, supra note 67, at L\&C 10.

259. See Provisions of the Criminal Code Amendment, supra note 16, at 38.

260. See generally id. at 97.

261. See Reference: Criminal Code Amendment, supra note 67, L\&C 34.

262. See supra Part (II)(C)(vi).

263. Provisions of the Criminal Code Amendment, supra note 16, at 5 .

264. Id.

265. Letter from Electronic Frontiers Australia, Inc. to the Senate Legal and Constitutional Committee, supra note 16.

266. Id. 
covers material which does not concern a particular device. ${ }^{267}$ Thus, the Act prohibits "accessing and making available material by means of the Internet and other carriage services that would ... remain lawful to import, export, access and distribute by other methods." 268

Third, the offenses in this Act go beyond the state law offenses for assisted suicide. ${ }^{269}$ Under state law, a person must actually aid or abet another in committing or attempting to commit suicide. ${ }^{270}$ Under the Suicide Related Material Offenses Act, if a person intends to use material over a carriage service to counsel or incite another to commit suicide, then an offense has been committed. $^{271}$ Distributing material across the carriage services is unnecessary. ${ }^{272}$

Fourth, the Act has no international reach. ${ }^{273}$ It cannot criminalize international communication encouraging suicide or describing methods of suicide; it will only keep Australians from participating in this communication. ${ }^{274}$ Further, it will be difficult to block material from internationally hosted sites because the regulation did not properly define the type of material that violates the Act. ${ }^{275}$

Fifth, the penalties for the Act are monetary instead of penal. ${ }^{276}$ The other provisions in the Criminal Code impose imprisonment. ${ }^{277}$ It is unclear why the legislature made this choice. ${ }^{278}$ One possibility is that the Act exists, not to protect the vulnerable, but to destroy voluntary euthanasia groups, a desire of conservative and religious organizations. ${ }^{279}$

267. Id.

268. Id. In recognizing the Act does cover a broader range of material, Parliament stated the Act was meant to compliment the Regulations and to prevent circumvention of the Customs Regulations through the internet. Letter from the Attorney General's Department to the Senate Legal and Constitutional Committee, supra note 168.

269. Suicide Related Material Offenses Bills Digest, supra note 87.

270. Id.

271. Id. For example, if a person obtained a book regarding how to commit suicide from the library with the intention of giving it to another person, then no offense has occurred under State law. Id. However, if a person obtained information on committing suicide with the intent to pass it to another over a carriage service, then there has been a violation of the Suicide Related Material Offenses Act. Id.

272. Id. See also Criminal Code Amendment (Suicide Related Material Offenses) Act, § 474.29B, 2005 (Austl.), available at http://www.austlii.edu.au/au/legis/cth/num_act/ccarmoa2005n922005479.

273. Provisions of the Criminal Code Amendment, supra note 16, at 29 (dissenting report of Senator Brian Grieg).

274. Reference: Criminal Code Amendment, supra note 67, at L\&C 30.

275. Id. One option to keep these international websites out would be to institute the "great Australian firewall," but that is an impractical solution merely to block just this type of material. Id.

276. Id. at L\&C 32. See Suicide Related Material Offenses Act.

277. Reference: Criminal Code Amendment, supra note 67, at L\&C 32.

278. See Suicide Related Material Offenses Act.

279. Provisions of the Criminal Code Amendment, supra note 16, at 29 (Dissenting report of Senator Brian Grieg). The Voluntary Euthanasia Society of New South Wales (VESNSW) 
Sixth, it is unclear on how to enforce the Act. ${ }^{280}$ To enforce the Act properly, critics note, the government would have to double the police force. ${ }^{281}$ "It is unrealistic to expect that the police will conduct a costly, comprehensive and concerted effort against discussion over a carriage service."282 Judicial enforcement of assisted suicide cases is also not high, with juries hesitant to convict and judges sentencing minimal penalties. ${ }^{283}$

\section{vii. Ways to Improve Bill}

Even those submissions that supported the Suicide Related Material Offenses Act still found the Act needed improvements. ${ }^{24}$ One proposal calls for stiffer penalties to exist when a person actually commits suicide because of another's offenses against the Act. ${ }^{285}$ For example, if a suicide does occur, then the state could enforce a ten-year imprisonment upon the person who aided the deceased. ${ }^{286}$

A second addition suggested by supporters of the Act is liability for Internet Service Providers (ISPs) ${ }^{287}$ Currently, the Act does not prevent access to international websites through Australian ISPs. ${ }^{288}$ In turn, the state would not penalize ISPs for allowing access to these sites because the ISPs lack the requisite intent to counsel, incite, or violate any other offenses of the Act. ${ }^{289}$ Therefore, supporters would like to amend the Act that makes ISPs liable in certain circumstances. ${ }^{290}$ Once the person responsible for the ISP is aware of a

recognized this legislation will "stifle, hamper and inhibit the work of [Voluntary Euthanasia Societies]" in Australia. Letter from Voluntary Euthanasia Society of New South Wales to the Senate Legal and Constitutional Committee, available at http://www.aph.gov.au/senate/committee/legcon_cttee/suicide/submissions/sub5.pdf (last visited Jan. 12, 2008). This society addressed the need for debate in a democratic Australia and the realization that the Suicide Related Material Offenses Act only benefits one side of the argument, those who are against euthanasia. Id. In its submission, the VESNSW pointed out that the creation of this legislation may have been to hinder the work of Dr. Philip Nitschke and his organization, Exit International, in fighting for the right to voluntary euthanasia. Id.

280. Kanck, supra note 133. In her speech, Kanck questions how the law enforcers will "check all the phone calls and e-mails." Id. She also questions the importance of finding these offenses because she assumes law enforcement has better things to do, like "policing real crime." Id.

281. Letter from Jocelyn Head to the Senate Legal and Constitutional Committee, supra note 3.

282. Id.

283. Id.

284. See Letter from the Coalition for the Defense of Human Life to the Senate Legal and Constitutional Committee, supra note 86. See also Reference: Criminal Code Amendment, supra note 67, at L\&C 29.

285. Letter from Coalition for the Defense of Human Life Submission to the Senate Legal and Constitutional Committee, supra note 86.

286. Id.

287. Id.

288. Reference: Criminal Code Amendment, supra note 67, at L\&C 30.

289. Letter from the Coalition for the Defense of Human Life to the Senate Legal and Constitutional Committee, supra note 86.

290. Id. 
website containing material in violation of the Act, he must take reasonable measures to block the website. ${ }^{291}$ The suggested penalty for this is $\$ 110,000$ AUD. ${ }^{292}$

Should Parliament choose to add such a provision, more problems may arise concerning the freedom of political communication. ${ }^{293}$ If an ISP could be liable for information that it was aware could violate the Suicide Related Material Offenses Act without having the intention to use the material to commit any of the offenses under the Act, ${ }^{294}$ then one could say the same for those participating in freedom of political communication. This means those making statements under political discussion for law reform who are aware the statements could violate the Act, but do not have the intent for the material to commit an offense, could be held criminally liable for violating the Act. ${ }^{295}$ Therefore, it would be unwise for Parliament to make a provision holding ISPs liable. $^{296}$

\section{E. Brief Conclusion of the Australian Suicide Related Material Offenses} Act 2005.

After a careful examination, it appears the state has not yet convicted anyone under the Suicide Related Material Offenses Act. ${ }^{297}$ Perhaps this is because of the difficulty in policing the listed offenses. ${ }^{298}$ Another possibility could be the difficulty in showing the requisite intent to commit an offense. ${ }^{299}$ Whatever the reason may be, it remains to be determined how this legislation will shape the phenomenon of cybersuicide in Australia and internationally. It certainly has made other nations give notice to this problem. ${ }^{300}$

291. Id.

292. Letter from Jocelyn Head to the Senate Legal and Constitutional Committee, supra note 3.

293. See supra Part II (D)(iv)(a).

294. Letter from the Coalition for the Defense of Human Life to the Senate Legal and Constitutional Committee, supra note 86.

295. But see Letter from the Attorney General's Department to the Senate Legal and Constitutional Committee, supra note 168.

296. See Letter from Suzanne Shipard, Australian Broadcasting Authority, to the Senate Legal and Constitutional Committee (Aug. 23, 2004), available at http://www.aph.gov.au/senate/committee/legcon_ctte/suicide/submissions/sub20.pdf.

297. Research through Lexis, WestLaw, Australia FindLaw, and Australian Legal Information Institute did not yield results in case history for the Suicide Related Material Offenses Act 2005.

298. See Kanck, supra note 133.

299. See supra Part (II)(D)(ii)(d).

300. See infra Part III. See also Right to Die: Censorship Move in Germany, http://assistedsuicide.org/blog/2006/04/14/right-to-die-censorship-move-in-germany/ (Apr. 14, 2006) (discussing proposed legislation in Germany which would make it difficult to provide information on assisted suicide, in general and on the internet). 


\section{THE UNITED KINGDOM'S DESIRE TO DEAL WITH CYBERSUICIDE THROUGH LEGISLATION}

Along with Australia, the United Kingdom has opened its eyes to the problem of cybersuicide inside its borders. ${ }^{301}$ Part A of this section will detail the problem of cybersuicide in the United Kingdom. Part B will discuss the options the United Kingdom's Parliament considered and why they have failed-leaving the United Kingdom still searching for a solution.

\section{A. The United Kingdom's Problem with Cybersuicide}

Since 2001, the United Kingdom has lost at least fifteen teenagers to internet related suicide. ${ }^{302}$ In 2004, Sarah Cherry purchased Final Exit from Amazon.com after discussing suicide in an internet chat room. ${ }^{303}$ This book taught her how to commit suicide and she used its lessons to take her own life. ${ }^{304}$ In 2005, two strangers committed suicide together in the parking lot of a shopping center after meeting in an internet chat room and discussing their desires to commit suicide. ${ }^{305}$ Noticing this rapidly growing problem, the Lancashire Evening Post started a campaign entitled "Stop the peddlers of death." 306 Prime Minister Tony Blair joined the campaign in order to garner more support to fight this phenomenon. ${ }^{307}$

\section{B. The Desire of the United Kingdom's Parliament to Protect the} Public from Internet Suicide

The United Kingdom has recognized that websites and chat rooms encouraging the vulnerable to commit suicide are dangerous, but these websites are not illegal or controlled by another regulatory body. ${ }^{308}$ Parliament has discussed at least two options to cover this field: using the Suicide Related Material Offenses Act as a model or amending the 1961 Suicide Act. ${ }^{309}$

301. See Charity in Suicide Websites, supra note 12.

302. Id.

303. 430 PARL. DEB., H.C. $\left(6^{\text {th }}\right.$ ser. $)(2005) 276$.

304. Id.

305. Ian Cobain, Clampdown on Chatrooms after Two Strangers Die in First Internet Death Pact, THE GUARDIAN, Oct. 11, 2005, available at http://www.guardian.co.uk/uk_news/story/0,,1589260,00.html.

306. 430 PARL. DEB., H.C. $\left(6^{\text {th }}\right.$ ser.) (2005) 276.

307. I'll Fight Internet Suicide, LANCASHIRE EVENING POST, Jan. 10, 2005, available at http://www.lep.co.uk/ViewArticle.aspx?sectionID=1789\&ArticleID=917087.

308. Goodenough, supra note 2.

309. See 430 PARL. DEB., H.C. $\left(6^{\text {th }}\right.$ ser.) (2005) 279. 


\section{i. $\quad$ The difference in United Kingdom law keeps Parliament from following Australia's legislation}

Some have suggested to Parliament that the United Kingdom could attempt to adopt legislation similar to the Suicide Related Material Offenses in Australia. $^{310}$ Due to the manner in which UK law has developed, this option does not seem viable. ${ }^{311}$

The United Kingdom believes "actions are legal or illegal according to their merits, rather than according to the medium used."312 Therefore, it stands whatever is considered illegal online would be illegal offline. ${ }^{313}$ Therefore, if the United Kingdom followed Australia and made it illegal to post methods of suicide online, for example, then works of fiction that depicted methods of suicide would become illegal. ${ }^{314}$

\section{ii. The difficulty in amending the 1961 Suicide Act to handle cybersuicide}

Papyrus, a United Kingdom charity, urged Parliament to amend the 1961 Suicide Act. ${ }^{315}$ This Act makes a person criminally liable for "aid[ing], abet[ting], counsel[ing], or procure[ing] the suicide of another, or an attempt by another to commit suicide. ${ }^{316}$ The punishment is imprisonment for a term not exceeding fourteen years. $^{317}$ The law requires that an individual have knowledge and have participated in the suicide for the state to prosecute them successfully. $^{318}$

However, Parliament wrote the 1961 Suicide Act before the advent of the internet; ${ }^{319}$ therefore, the Act is "woefully inadequate to deal with the use of the internet for the promotion of suicide." 320 First, Parliament recognized that amending the Act might not provide adequate results because U.K. law would not apply to sites hosted abroad. ${ }^{321}$ Second, the unique features of the internet allow the author or source of information to remain anonymous. ${ }^{322}$ Lastly, the statutory interpretation of the Act would make it difficult to apply or adapt to cybersuicide. The Act requires a direct causal link between the information

310. Id.

311. Id. at 282 .

312. Id. at 281 .

313. Id. For example, the Obscene Publications Acts covers material both online and offline. Id.

314. Id. at 282.

315. Call to Ban Pro-suicide Websites, supra note 33.

316. Suicide Act, 1961, 1961, U.K. Stat. 1961, 9 \& 10 Eliz. 2 c. 60 , § 2 (Eng.).

317. Id.

318. Call to Ban Pro-suicide Websites, supra note 33.

319. Charity in Suicide Websites, supra note 12.

320. See 430 Parl. Deb., H.C. (6 ${ }^{\text {th }}$ ser.) (2005) 277.

321. Call to Ban Pro-suicide Websites, supra note 33.

322. 430 PARL. DEB., H.C. $\left(6^{\text {th }}\right.$ ser.) (2005) 277. 
provided or the procurement and the actual suicide. ${ }^{323}$ Parliament finds it unlikely that participation in a suicide will occur by those producing cybersuicide websites. $^{324}$ In addition, it would be difficult to show that counseling in websites was sufficient for a direct causal link. ${ }^{325}$ Providing information on suicide methods would not constitute an offense under the Act. $^{326}$

\section{The United Kingdom's Current Solution to Cybersuicide}

The United Kingdom has acted to solve the problem of cybersuicide through a non-legislative capacity. ${ }^{327}$ First, the Samaritans ${ }^{328}$ are in negotiations with internet service providers, such as Yahoo! and AOL, to "reprioritise the results" retrieved during an internet search of suicide. ${ }^{329}$ An official stated "[w]hen somebody keys in 'suicide' and 'UK' we would like them to be offered a link to the Samaritans long before they find a website showing them what they can do with a car exhaust and a hose pipe."330 Papyrus has also suggested that the Department of Health should amen its National Suicide Strategy to warn on the dangers of the Internet. ${ }^{331}$ Lastly, the government is encouraging internet service providers to provide filters to protect the vulnerable from such websites. ${ }^{332}$

\section{CONCLUSION}

It is undeniable that cybersuicide has emerged as a real problem; however, it is a difficult phenomenon to regulate on an international level. First, assisted-suicide is not illegal in every country; therefore, the citizens in countries in which it is legal should be able to access this type of information over the internet. ${ }^{333}$ Secondly, the nature of the internet blurs "conventional

323. Id. at 282. "There must be participation in the act of suicide, as well as a knowledge of what is going to take place." Id.

324. Id.

325. Id.

326. Id.

327. Charity in Suicide Websites, supra note 12.

328. Samaritans is a group which provides assistance twenty-four hours a day to those experiencing suicidal thoughts. Samaritans.org, About Samaritans, http://www.samaritans.org/about_samaritans.aspx (last visited May 23, 2008).

329. Cobain, supra note 305 .

330. Id.

331. Call to Ban Pro-suicide Websites, supra note 33.

332. 430 PARL. DEB., H.C. (6 ${ }^{\text {th }}$ ser.) (2005) 277.

333. Assisted suicide is legal in Oregon, Switzerland, Belgium, and the Netherlands. Derek Humphry, Tread Carefully When You Help to Die: Assisted Suicide Laws around the World, AsSISTEDSUICIDE.ORG, Mar. 1, 2005, http://www.assistedsuicide.org/suicide_laws.html. Another concern is how countries deal with freedom of expression. For example, censoring cybersuicide websites in America would be difficult because it would potentially violate the First Amendment. 430 PARL. DEB., H.C. $\left(6^{\text {th }}\right.$ ser.) (2005) 279. 
methods of jurisdiction." 334 Accordingly, the internet presents legislatures worldwide with a global problem. ${ }^{335}$

In considering regulation of cybersuicide, legislatures need to consider the construction of assisted-suicide statutes. ${ }^{336}$ As it has been shown, whether the regulation of cybersuicide is even possible depends on the construction of these statutes. ${ }^{337}$ This does not mean it is impossible to inhibit cybersuicide. Internet service providers can provide filters and encourage use by the users to implement the filters to block as much of this type of content as possible. ${ }^{338}$ Also, those websites which offer counseling services to those in need can ensure their meta tags include terms one would use while looking for cybersuicide websites. ${ }^{339}$ These are just some of the options available to governments around the world to protect their citizens from the phenomenon of cybersuicide.

334. Hanley, supra note 31 , at 998 . Hanley's Note suggests a multi-national approach to regulating the internet. Id. First, the article suggests there should be a flexible regulatory structure to allow nations to choose their degree of regulation. Id. Second, the article discusses the relationship between ISPs and national governments and the need for governments to express control over ISPs. Id. at 999.

335. See generally id.

336. See e.g. 430 PARL. DEB., H.C. $\left(6^{\text {th }}\right.$ ser.) (2005) 276-84.

337. See e.g. id..

338. See e.g. 430 PARL. DEB., H.C. $\left(6^{\text {th }}\right.$ ser.) (2005)276-84.

339. Letter from Electronic Frontiers Australia, Inc. to the Senate Legal and Constitutional Committee, supra note 16. 
